\title{
In silico pathway analysis based on chromosomal instability in breast cancer patients
}

\author{
Akeen Kour ${ }^{1}$, Vasudha Sambyal ${ }^{1 *}$ D, Kamlesh Guleria ${ }^{1}$, Neeti Rajan Singh² ${ }^{2}$ Manjit Singh Uppal ${ }^{2}$, Mridu Manjari ${ }^{3}$ \\ and Meena Sudan ${ }^{4}$
}

\begin{abstract}
Background: Complex genomic changes that arise in tumors are a consequence of chromosomal instability. In tumor cells genomic aberrations disrupt core signaling pathways involving various genes, thus delineating of signaling pathways can help understand the pathogenesis of cancer. The bioinformatics tools can further help in identifying networks of interactions between the genes to get a greater biological context of all genes affected by chromosomal instability.

Methods: Karyotypic analyses was done in 150 clinically confirmed breast cancer patients and 150 age and gender matched healthy controls after $72 \mathrm{~h}$ Peripheral lymphocyte culturing and GTG-banding. Reactome database from Cytoscape software version 3.7.1 was used to perform in-silico analysis (functional interaction and gene enrichment).

Results: Frequency of chromosomal aberrations (structural and numerical) was found to be significantly higher in patients as compared to controls. The genes harbored by chromosomal regions showing increased aberration frequency in patients were further analyzed in-silico. Pathway analysis on a set of genes that were not linked together revealed that genes HDAC3, NCOA1, NLRC4, COL1A1, RARA, WWTR1, and BRCA1 were enriched in the RNA Polymerase II Transcription pathway which is involved in recruitment, initiation, elongation and dissociation during transcription.

Conclusion: The current study employs the information inferred from chromosomal instability analysis in a nontarget tissue for determining the genes and the pathways associated with breast cancer. These results can be further extrapolated by performing either mutation analysis in the genes/pathways deduced or expression analysis which can pinpoint the relevant functional impact of chromosomal instability.
\end{abstract}

Keywords: Chromosomal instability, Breast cancer, Pathway analysis

\section{Background}

Complex genomic changes that arise in tumors are a consequence of Chromosomal Instability (CIN), which leads to numerical $[(\mathrm{N})-\mathrm{CIN}]$ as well as structural chromosomal instability [(S)-CIN] [1]. The increased levels of aneuploidy and structural complexity in these tumors

\footnotetext{
*Correspondence: vasudhasambyal@yahoo.co.in

${ }^{1}$ Human Cytogenetics Laboratory, Department of Human Genetics, Guru

Nanak Dev University, Amritsar, Punjab, India

Full list of author information is available at the end of the article
}

indicate errors in DNA repair, mitotic segregation and cell cycle checkpoints $[2,3]$ and may cause $(\mathrm{N})$-CIN. Structural rearrangements emerge by anomalous DNA repair pathways that cause abnormalities in both homologous and non-homologous end-joining of doublestranded DNA $[4,5]$. (S)-CIN may also appear through telomere-mediated events, where decisively short telomeres get identified as DNA breaks capable of recombining (either homologously or nonhomologously) when DNArepair pathways get compromised and leads to activation of telomerase [6]. The mechanism leading to aneuploidy 
is distinct from structural changes and aneuploidy arises by disruptions in cell cycle checkpoints and errors in mitotic segregation $[2,7]$.

CIN is clinically important as it is associated with poor outcome in patients with cancers of lung, breast and colon [8-10] leading to loss or gain of chromosome segments, deletions, translocations, and DNA amplifications [11]. Various studies have reported the correlation between chromosomal aberration and tumor grade and prognosis $[8,12]$. Cytogenetic studies in cancer cells have recognized the complexity of genomic rearrangements in cancer cells [13] and have reported recurrent abnormalities in a broad range of tumors $[14,15]$.

A link between aneuploidy and/or CIN and poor clinical outcome has been identified by several studies [16]. Cancer cells can be targeted based on the whole chromosome instability (W-CIN) phenotype they carry. National cancer Institute (NCI), USA screened compounds having anticancer activity by examining the data-rich drug discovery panel of NCI-60 cancer cell lines and enlisted potential agents with anticancer activity which targeted chromosomally unstable and aneuploid cancer cells [1719]. NCI also provided a confirmation of the possibility of discovering potential anticancer agents based on the link between their activity and the karyotypic state. An association between aneuploidy and chromosomal instability with distinctive clinical and histopathological features and poor prognosis has also been reported in various cancers [20-22]. Thus, the need to target CIN with new combinatorial strategies has been suggested [23].

Data from large scale genome wide projects have unveiled common core signaling pathways which lead to the development of various cancers [24-28]. Studies to delineate pathways involved in pathogenesis of cancers like colon and glioblastoma multiforme [29], have provided characterization of the genes involved in the pathogenesis of the disease, thus making it significant to focus on pathways which involve various genes [30, 31]. Genomic aberrations disrupt signaling cascades or pathways in tumor cells thereby causing the tumor to proliferate or dedifferentiate uncontrollably [32]. For instance, deletion in any of the components of TGF $\beta$ pathway paves way for some of the breast cancers [33-37]. Therapeutic targeting of pathways that are directly involved in initiation of CIN has also gained clinical interest [20,38]. Pathways-based analysis has gained much importance in the past decade as it is able to, firstly identify the actual genes associated with the phenotype and demarcates them from other false positive hits [39] and secondly marks the biological pathways affected by the genes [40].

The bioinformatics approach can further help in identifying networks of interactions between the genes of interest as well to simultaneously identify biologically informative "linker" genes so as to get a greater biological context of all genes affected by chromosomal instability. This can help to stratify breast cancer patients for choosing optimal treatments and therapies.

Karyotyping aids in efficient single cell screening and identifies important genomic aberrations in normal or diseased samples [41]. A copy number alteration (CNA) is represented by any alteration in banding pattern [42]. This has been indicated by studies which have reported a relation between chromosomal anomalies in peripheral blood lymphocytes (PBLs) and risk prediction in cancers [43-46]. Blood-test screening is considered a non-invasive, cost effective technique [41]. Also, genetic aberrations in a non-target tissue like PBLs may display related events in target tissue [47].

The present study therefore aimed to identify chromosomal anomalies in PBLs of breast cancer patients to: a) identify the recurring aberrant chromosomal lesions and chromosomal loci that are frequently involved in breast cancer; b) determine the genes harboured by these regions, and to delineate the biological pathway which is enriched by them by bioinformatic tools.

\section{Methods}

In the present study 150 patients with confirmed malignant breast cancer were included. The patients were clinically investigated at Sri Guru Ram Das Institute of Medical Sciences and Research, Vallah, Amritsar, Punjab, India. This study was conducted after approval by the institutional ethical committee of Guru Nanak Dev University, Amritsar, Punjab, India. Patients with confirmed malignant breast cancer without any history of any other cancer were included in the study whereas patients having received any kind of therapy (chemotherapy, hormone therapy, radiotherapy or surgery) or blood transfusion, prior to sampling were excluded from the study. After informed consent relevant information including age, gender, occupation, personal history, habitat, habits and disease history were recorded in pre-designed questionnaire. The blood samples of 150 patients and 150 sex and gender matched healthy controls (with no family history of cancer) were collected in a heparinized vial. Peripheral Lymphocyte Culturing was performed by standard $72 \mathrm{~h}$ culture method using phytohemagglutinin as mitogen. GTG banding was performed and karyotyping was done following ISCN 2016 [48]. Chromosomal anomalies were assessed in 50-100 metaphases for each subject.

The genes (Table 4) present on the chromosomes involved in anomalies were retrieved from Atlas of Genetics and Cytogenetics in Oncology and Hematology [49] and Genatlas database [50]. On the homepage of Atlas of Genetics and Cytogenetics in Oncology and Hematology, the chromosome number was selected from 
'ENTITIES: by chromosomal band' and then the genes present on the particular location/band were identified. On the homepage of Genatlas Database, the list of genes present on a particular chromosomal location/band was retrieved by entering the chromosome number and band in "SEARCH in GENATLAS GENES" search field.

Reactome database from Cytoscape software version 3.7.1 was used to perform functional interaction and gene enrichment analysis on the genes (query genes) that were present on the chromosomal regions that were frequently involved in cytogenetic anomalies in the current study. In the Apps menu on Cytoscape software 'Reactome FI' was selected. After clicking on this menu, six sub-menus appeared out of which 'Gene Set/Mutation Analysis' was selected for performing FI (Functional interaction) analysis on a set of genes. Functional Interaction analysis revealed the involvement of various genes (linker genes) that were linked to the query genes through different networks (Fig. 1).

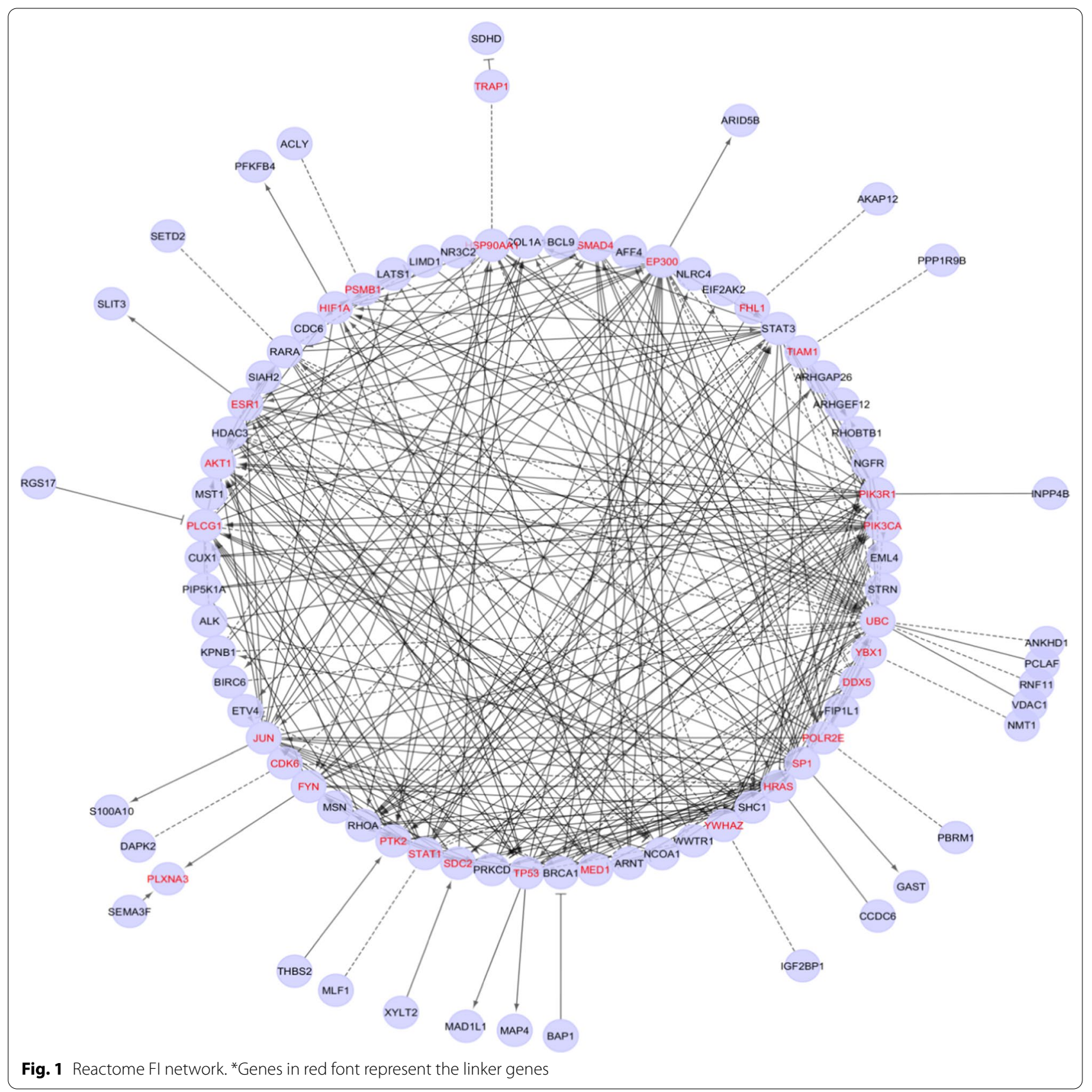


As majority of the patients (86\%) had Infiltrating Ductal Carcinoma (IDCa) of breast, pathway enrichment for invasive ductal breast carcinoma was performed to identify the genes invloved in IDCa. The important features of Reactome FI plug-in were invoked from a pop-up menu by right clicking on the empty space in the network view panel. 'Load Cancer Gene Index' option in the pop-up menu opened a list of NCI diseases in the control panel. Here, below 'Disease Hierarchy', following options were chosen: Neoplasm-Neoplasm by site-Breast Neoplasm-Malignant Breast Neoplasm-Breast Carcinoma-Breast Adenocarcinoma-Ductal Breast Carcinoma-Invasive Ductal Carcinoma.

Pathway enrichment analysis was further done on a set of genes that are not linked together by checking 'show genes not linked to others' in FI Network Construction Parameters. Linkers were not used for pathway enrichment analysis as it leads to bias in results. Right clicking on the empty space in the network view panel led to a pop-menu from which following options were subsequently chosen: Reactome FI - Analyze Network Functions - Pathway Enrichment.

\section{Results}

\section{Cytogenetic analysis}

Cytogenetic analysis was performed on 150 breast cancer patients (147 females and 3 males) and 150 age and gender matched controls. Out of 150 patients, 20 (13.3\%), 74 (49.3\%), $37(24.7 \%)$ and $14(9.3 \%)$ were diagnosed with stage I, Stage II, stage III and stage IV breast carcinoma, respectively. Exact stage of $5(3.3 \%)$ patients could not be determined. Majority of the patients (89.3\%) had IDC of breast. The chromosomal aberrations were counted as in metaphases with: only structural aberrations, with only numerical aberrations and metaphases with both structural and numerical aberrations. A few karyotypes illustrating these aberrations have been provided as Additional file 1: figures (Figure S1-S7). The difference in the frequencies of chromosomal aberrations amongst patients and controls was statistically significant (Table 1). The aberrations were higher in patients as compared to controls: mean (\%) aberrant metaphases $(22.6 \pm 12.3$ vs. $12.5 \pm 4.6, \mathrm{p}<0.0001)$, mean (\%) metaphases with structural aberrations $(11.7 \pm 10.8$ vs. $4.5 \pm 3.1, \mathrm{p}<0.0001)$, mean (\%) metaphases with numerical aberrations $(9.5 \pm 6.7$ vs. $6.2 \pm 3.5$; $\mathrm{p}<0.0001)$. However, mean (\%) metaphases with both structural and numerical aberrations were similar in both the groups $(2.6 \pm 2.0$ vs. $2.6 \pm 1.1 ; \mathrm{p}=1.00)$.

The stage-wise comparison of cytogenetic profile of breast cancer patients with controls has been shown in Table 2. The chromatid type aberrations observed in patients included premature centromeric division, chromatid break and gap while the chromosome type aberrations included polyploidy, chromosomal gap, pulverizatrion, telomeric associations, chromosomal break, endoreduplication, robertsonian translocations, acentric fragments, ring chromosomes, deletions. Association between the acrocentric chromosome 13, 14, 15, 21 and 22 were scored separately in all metaphases. Acrocentric associations and telomeric bridges were also scored but not counted in the total aberrations. Telomeric associations were commonly seen in acrocentric chromosomes. Apart from acrocentric chromosomes, chromosome 1, 2, $16,18,20$ and $\mathrm{X}$ were also frequently involved in telomeric associations. Breaks and gaps were the most frequent structural chromosomal aberration observed in various regions of different chromosomes. The chromosomes frequently involved in aberrations like loss, gain, deletion, addition and translocations have been shown in Table 3 .

Chromosomal aberrations present in $2 \%$ or more that $2 \%$ of metaphases in an individual were considered as clonal anomalies. Both structural and numerical clonal chromosomal anomalies were observed in 28 breast cancer patients (Additional file 1: figure S8, S9). Clonal structural chromosomal anomalies observed in 5 cases were: [(46,XX, add(1)(pter $\rightarrow$ q21::?::q21 $\rightarrow$ qter $)]$, $[45, \mathrm{XX}, \operatorname{del}(2)($ pter $\rightarrow$ q11.2::21.2 $\rightarrow$ qter $)],[46, X X, \mathrm{i}($ 21)(q10;q10)], [46,XX,?add(1)(q?21)], [45,XX,t $(1 ; 5)$ $(5$ pter $\rightarrow$ 5q23::1q25 $\rightarrow$ qter)]. Noticeably, chromosome

Table 1 Cytogenetic profile of breast cancer patients and controls

\begin{tabular}{lllr}
\hline & Patients & Controls & p-value \\
\hline No. of subjects & 150 & 150 & 0.51 \\
Age (Mean \pm SD) & $50.2 \pm 11.5$ & $49.2 \pm 14.6$ & $<.0001$ \\
Mean (\%) aberrant metaphases & $22.6 \pm 12.3$ & $12.5 \pm 4.6$ & $4.5 \pm 3.1$ \\
Mean (\%) metaphases with structural aberrations & $11.7 \pm 10.8$ & $6.2 \pm 3.5$ & $<.0001$ \\
Mean (\%) metaphases with numerical aberrations & $9.5 \pm 6.7$ & $2.6 \pm 1.1$ & $\mathbf{< . 0 0 0 1}$ \\
Mean (\%) metaphases with both structural and numerical aberrations & $2.6 \pm 2.0$ & $28.9 \pm 14.6$ & 1.00 \\
Mean(\%) metaphases with acrocentric associations & $27.6 \pm 14.7$ & & 0.32 \\
\hline
\end{tabular}

Significant $p$-value $(<0.05)$, calculated by t-test, are shown in bold 
Table 2 Comparison of cytogenetic profile of Breast cancer patients stage-wise and matched controls

\begin{tabular}{|c|c|c|c|c|c|c|}
\hline S.No & Patient group and controls & Mean (\%) TAM & Mean (\%) MSA & Mean (\%) MNA & $\begin{array}{l}\text { Mean (\%) } \\
\text { M(SA + NA)\# }\end{array}$ & Mean MAA (\%) \\
\hline 1 & $\begin{array}{l}\text { Stage I cases }(n=20) \\
\text { Controls }(n=20) \\
\text { p-value }\end{array}$ & $\begin{array}{l}20.6 \pm 7.6 \\
10.3 \pm 3.0 \\
<\mathbf{0 . 0 0 0 1}\end{array}$ & $\begin{array}{l}9.3 \pm 5.8 \\
4.7 \pm 3.1 \\
\mathbf{0 . 0 0 3 4}\end{array}$ & $\begin{array}{l}9.2 \pm 5.0 \\
4.5 \pm 3.2 \\
\mathbf{0 . 0 0 1 1}\end{array}$ & $\begin{array}{l}3.0 \pm 2.3 \\
1.2 \pm 1.1 \\
\mathbf{0 . 0 0 3 1}\end{array}$ & $\begin{array}{l}28.6 \pm 13.5 \\
30.2 \pm 11.8 \\
0.069\end{array}$ \\
\hline 2 & $\begin{array}{l}\text { Stage } \| \text { cases }(n=74)^{*} \\
\text { Controls }(n=74) \\
\text { p-value }\end{array}$ & $\begin{array}{l}12.0 \pm 9.2 \\
12.9 \pm 5.0 \\
0.4609\end{array}$ & $\begin{array}{l}13.1 \pm 9.2 \\
4.7 \pm 3.2 \\
<\mathbf{0 . 0 0 0 1}\end{array}$ & $\begin{array}{l}9.4 \pm 6.2 \\
6.3 \pm 3.4 \\
\mathbf{0 . 0 0 0 2}\end{array}$ & $\begin{array}{l}2.2 \pm 1.5 \\
2.0 \pm 1.4 \\
0.4031\end{array}$ & $\begin{array}{l}28.3 \pm 15.0 \\
29.6 \pm 15.0 \\
0.5989\end{array}$ \\
\hline 3 & $\begin{array}{l}\text { Stage III cases }(n=37) \\
\text { Control }(n=37) \\
\text { p-value }\end{array}$ & $\begin{array}{l}21.7 \pm 12.1 \\
11.9 \pm 4.1 \\
<\mathbf{0 . 0 0 0 1}\end{array}$ & $\begin{array}{l}10.6 \pm 7.9 \\
4.1 \pm 2.8 \\
\mathbf{0 . 0 0 1 5}\end{array}$ & $\begin{array}{l}9.4 \pm 7.5 \\
6.3 \pm 3.4 \\
\mathbf{0 . 0 2 5 0}\end{array}$ & $\begin{array}{l}3.5 \pm 2.8 \\
1.5 \pm 1.2 \\
\mathbf{0 . 0 0 0 2}\end{array}$ & $\begin{array}{l}26.0 \pm 13.2 \\
18.9 \pm 17.9 \\
0.0561\end{array}$ \\
\hline 4 & $\begin{array}{l}\text { Stage IV cases }(n=14) \\
\text { Controls }(n=14) \\
\text { p-value }\end{array}$ & $\begin{array}{l}22.2 \pm 9.7 \\
13.8 \pm 5.1 \\
\mathbf{0 . 0 0 8 1}\end{array}$ & $\begin{array}{l}10.9 \pm 7.2 \\
5.1 \pm 3.5 \\
\mathbf{0 . 0 1 1 7}\end{array}$ & $\begin{array}{l}10.2 \pm 9.2 \\
6.8 \pm 3.9 \\
0.2142\end{array}$ & $\begin{array}{l}2.1 \pm 1.0 \\
1.9 \pm 1.8 \\
0.7192\end{array}$ & $\begin{array}{l}31.6 \pm 19.3 \\
26.1 \pm 18.5 \\
0.4484\end{array}$ \\
\hline 5 & $\begin{array}{l}\text { Indeterminate stage } \\
\text { cases }(n=5) \\
\text { Controls }(n=5) \\
\text { p-value }\end{array}$ & $\begin{array}{l}16.7 \pm 2.4 \\
13.0 \pm 5.5 \\
0.2053\end{array}$ & $\begin{array}{l}4.7 \pm 3.3 \\
3.7 \pm 2.2 \\
0.5883\end{array}$ & $\begin{array}{l}11.5 \pm 3.3 \\
7.7 \pm 4.8 \\
0.1828\end{array}$ & $\begin{array}{l}1.0 \pm 0.0 \\
1.6 \pm 1.5 \\
0.3972\end{array}$ & $\begin{array}{l}24.6 \pm 8.1 \\
26.0 \pm 14.0 \\
0.8514\end{array}$ \\
\hline
\end{tabular}

Significant $\mathrm{p}$-value $(<0.05)$, calculated by t-test, are shown in bold

TAM total aberrant metaphases, MSA metaphases with structural aberrations, $M N A$ metaphases with numerical aberrations, $M(S A+N A):$ metaphases with structural and numerical aberrations, MAA metaphases with acrocentric associations

* One of the subjects with Stage II breast cancer had more than $90 \%$ frequency of structural aberration as it was a clonal chromosomal anomaly. Therefore, it was not included in the calculations. Similarly, one of the subjects with Indeterminate stage had a very higher frequency of structural aberrations, thus, it was not included in the calculations

\# The zero values were omitted during the calculation of Average and Standard Deviation due to the presence of high number of zero values in Mean(\%) M(SA + NA)

Table 3 Comparison of frequency of chromosomes involved in various aberrations in the breast cancer patients and controls

\begin{tabular}{|c|c|c|c|c|c|}
\hline \multirow[t]{2}{*}{ Type of aberration } & \multicolumn{2}{|l|}{ Cases } & \multicolumn{2}{|l|}{ Controls } & \multirow[t]{2}{*}{ p-value } \\
\hline & $\begin{array}{l}\text { Chromosomes/ } \\
\text { chromosome arms involved }\end{array}$ & Frequency & $\begin{array}{l}\text { Chromosomes/ chromosome } \\
\text { arms involved }\end{array}$ & Frequency & \\
\hline Loss & $5,8,16,17,18,19,20,21,22, x$ & $78.8 \pm 21.20$ & $8,9,15,17,19,20,22, x$ & $57.25 \pm 9.23$ & 0.0169 \\
\hline Gain & $2,3,8,9, x$ & $8.8 \pm 4.6$ & $3,4,6,16,21$ & $9.8 \pm 2.28$ & 0.674 \\
\hline Break & $1 p, 1 q, 2 p, 2 q, 3 q, 4 p, 4 q, 7 q, 9 q, 17 q$ & $12.43 \pm 5.29$ & $1 q, 2 q, 3 p, 3 q, 4 q, 16 q$ & $4.4 \pm 1.95$ & 0.0065 \\
\hline Gap & $1 p, 1 q, 2 p, 3 p, 3 q, 4 q, 5 q, 6 q, 9 q, 11 q$ & $4.25 \pm 2.19$ & $1 q, 2 q, 5 q, 14 q, 17 q$ & $1.8 \pm 0.84$ & 0.0334 \\
\hline Deletion & $1 p, 1 q, 2 q, 3 q, 4 q, 5 q, x q$ & $7.2 \pm 2.6$ & $1 p, 1 q, 5 p, 6 q, \times p$ & $4.2 \pm 1.1$ & 0.0264 \\
\hline Addition & $1 q, 9 q$ & & $9 q$ & NC & NC \\
\hline Translocations & $1,5,8,10,12, x$ & $4.83 \pm 1.47$ & $2,4,16$ & $2.66 \pm 0.57$ & 0.0475 \\
\hline Robertsonian translocation & 15,21 & $26.5 \pm 7.78$ & $13,21,22$ & $26.33 \pm 3.79$ & 0.9749 \\
\hline \multirow[t]{2}{*}{ Telomeric associations } & $1,2,3,12,16,18,19,20$ & $9.83 \pm 3.37$ & $7,19, x$ & $14.33 \pm 4.04$ & 0.1182 \\
\hline & $\begin{array}{l}\text { Acrocentric chromosomes: } 13,14,15 \text {, } \\
21,22\end{array}$ & $101 \pm 14.73$ & $\begin{array}{l}\text { Acrocentric chromosomes: } 13,14,15 \text {, } \\
21,22\end{array}$ & $44.8 \pm 11.19$ & 0.0008 \\
\hline Triradials & $15,21,22$ & $17 \pm 5.29$ & $14,15,21,22$ & $9.75 \pm 2.36$ & 0.0552 \\
\hline
\end{tabular}

Significant $p$-value $(<0.05)$, calculated by t-test, are shown in bold

1 was found to be involved in clonal anomalies in three of the cases. Clonal numerical chromosomal anomalies were observed in 23 cases. The most frequent was loss of chromosome $\mathrm{X}$ which was observed in 10 cases. Other clonal numerical anomalies included: loss of chromosome 7, 9, 16 and 22 in two cases each; and loss of chromosome 2, 8, 11, 13, 14, 17 and 20 in one case each.
The control subjects had predominantly normal karyotype and the chromosomal aberrations found were lesser in frequency as compared to cases. Moreover, no specific or recurring anomaly was observed in controls. Frequency of non-clonal chromosomal aberrations observed in control were: telomeric association 26.3\%; robertsonian translocation $14.3 \%$; premature centromeric division 
9.7\%; break 9.2\%; deletion 8.9\%; acentric fragments $8.2 \%$; marker chromosome $5.7 \%$; triradial $3.9 \%$; gap $3.2 \%$; translocation 2.3\%; endoreduplication $2.0 \%$; dicentric $2.0 \%$; double minute $0.9 \%$; polyploidy $0.9 \%$; addition $0.7 \%$; ring chromosome $0.5 \%$; fragile site $0.5 \%$; duplication $0.5 \%$; and inversion $0.4 \%$.

To identify the genes harbored by the chromosomal regions showing increased aberration frequency in present study sample, data was retrieved from Atlas of Genetics and Cytogenetics in Oncology and Hematology [49] and Genatlas database [50] (Table 4).

\section{In-silico analysis}

Functional Interaction analysis revealed the involvement of various genes (linker genes) that are linked to the query genes (observed to be harboured by the chromosomal region frequently involved in anomalies in the present study) through different networks (Fig. 1). Pathway enrichment for invasive ductal breast carcinoma was performed to identify the genes invloved in IDC as majority of the patients in the present study sample (89.3\%) had IDC of breast (Fig. 2). Linker genes that were involved in IDC were SMAD4, EP300, PIK3CA, TP53, HIF1A and AKT1.

We analyzed pathways on a set of genes that are not linked together by checking 'show genes not linked to others' in FI Network Construction Parameters. Pathway Enrichment analysis revealed that genes $H D A C 3$,
NCOA1, NLRC4, COL1A1, RARA, WWTR1, and BRCA1 are enriched in the RNA Polymerase II Transcription pathway (Fig. 3).

\section{Discussion}

Aneuploidy is thought to be a principal outcome of CIN [51]. Chromosomally unstable cancer cells undergo chromosomal missegrgation in excess of every fifth division $[52,53]$ in contrast to chromosomally stable cells with missegregation occurring in only $1 \%$ of cell divisions [52]. Mechanisms that seem to contribute to nCIN are aberrant sister chromatid cohesion [54-57], breach in mitotic checkpoint [58-61], amplification of centrosomes [62] and improper attachment of chromosomes to the mitotic spindle $[63,64]$. The whole-chromosome missegregation in mitosis is associated to structural aberrations and DNA damage in the following interphase $[65,66]$.

Genomes with CIN are characterized by various forms of structural genomic aberrations like amplifications, insertions, reciprocal and non-reciprocal translocations and deletions [5]. In the present study the frequency of various structural (both chromatid type and chromosomal type) and numerical chromosomal aberrations in patients were significantly higher than controls.

Chromosomes that were observed to be frequently involved in aberrations in patients in the present study were $1,2,3,4,5,8,9,17$ and X. Similar aberrations in these chromosomes have been associated with invasive

Table 4 Genes harboured by the chromosomal regions recurring in anomalies in present study sample

\begin{tabular}{|c|c|}
\hline Chromosomal region & Genes $^{a}$ \\
\hline $1 \mathrm{p} 32$ & RNF11 \\
\hline $1 \mathrm{q} 21$ & ARNT, SHC1, PIP5K1A, S100A10, BCL9, MAD1L1, PDE4DIP \\
\hline $2 \mathrm{p} 21$ & EML4 \\
\hline $2 \mathrm{p} 22$ & NLRC4, MSN, BIRC6, STRN, EIF2AK2 \\
\hline $2 \mathrm{p} 23$ & NCOA1, ALK \\
\hline $3 p 21$ & LIMD1, MAP4, RHOA, PFKFB4, MST1, SEMA3F, SETD2, PBRM1, BAP1, PBRM1, PRKCD \\
\hline $3 q 25$ & WWTR1, SIAH2, MLF1, RARRES1 \\
\hline $4 q 12$ & FIP1L1 \\
\hline $4 q 31$ & INPP4B, NR3C2 \\
\hline $5 q 31$ & AFF4, SLIT3, VDAC1, ANKHD1, HDAC3, ARHGAP26 \\
\hline $6 q 13$ & SMAP1 \\
\hline $6 q 25$ & RGS17, AKAP12, LATS1 \\
\hline $6 q 27$ & FGFR1OP, THBS2 \\
\hline $7 q 22$ & CUX1 \\
\hline $10 q 21$ & CCDC6, RHOBTB1, ARID5B \\
\hline $11 q 23$ & SDHD, ARHGEF12 \\
\hline $15 q 22$ & PCLAF, DAPK2 \\
\hline $17 q 21$ & $\begin{array}{l}\text { GSDMB, RARA, CDC6, STAT3, GAST, ACLY, BRCA1, ETV4, NMT1, KPNB1, IGF2BP1, } \\
\text { NGFR, XYLT2, PPP1R9B, COL1A1 }\end{array}$ \\
\hline
\end{tabular}

a Source: Atlas of Genetics and Cytogenetics in Oncology and Hematology [49] and Genatlas database [50] 


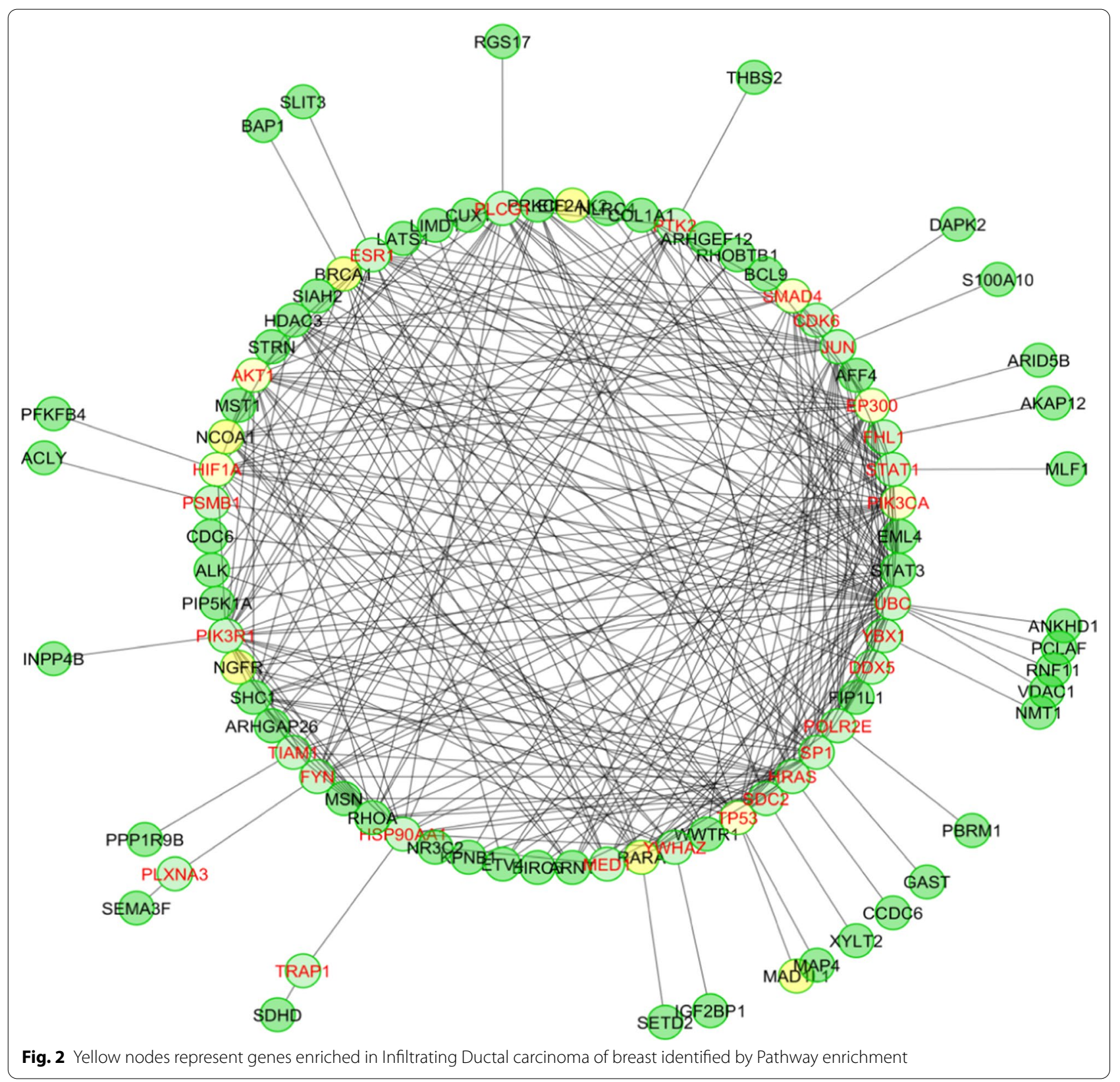

ductal carcinoma of breast and other subtypes [67-69]. Among these, chromosomes 8, 14, 4, 18, X, 3, 10, 20, 9 and 1 have also been observed to contain aberrant regions in breast cancer patients [70].

Large retrospective and prospective studies have given the evidence that the patients having tumors with high aneuploidy have a reduction in recurrence free survival rate that is half as long as those in patients with diploid distribution [71, 72]. Apart from describing the ploidy of DNA content, i.e. diploid or aneuploid, the ploidy-based classification has also been used to understand the degree of genomic instability which reveals the inconsistency of the DNA content in the tumor cell population [73, 74]. In patients with mosaic variegated aneuploidy, premature sister chromatid separation is observed in more than $50 \%$ of lymphocytes. In various tissues aneuploidy is seen in more than $25 \%$ cells and this enhanced level of aneuploidy leads to higher chances of cancer in these patients $[59,75]$.

The pathway analysis was performed by Reactome FI to find the linker genes. Pathway enrichment was then performed to further narrow down to the linker genes 


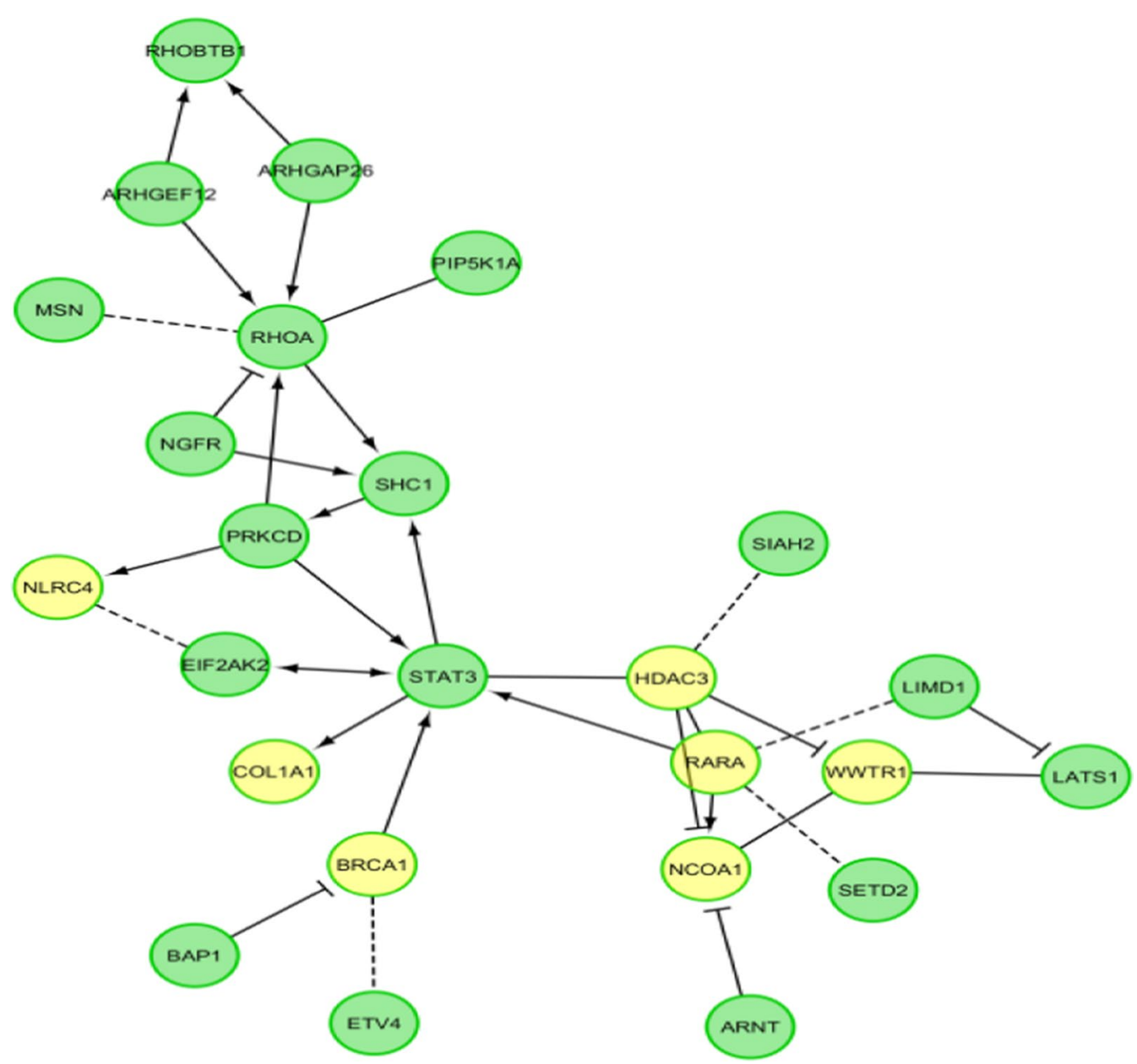

Fig. 3 Pathway in Fl sub-network. Genes highlighted in yellow color are the ones enriched in RNA polymerase II transcription pathway ( $p=0.002$, $F D R=0.01$ )

that were specifically involved in IDC of breast and the genes identified here were SMAD4, EP300, PIK3CA, TP53, HIF1A and AKT1. SMAD4 has been known to be mainly involved in pancreatic and colorectal cancer [76]. Mutations in EP300 have been frequently found in skin squamous cell carcinoma and various types of lymphomas [77]. PIK3CA has been reported in higher frequency in endometrial, breast and bladder cancers [78]. TP53 is a tumor suppressor gene and has been found to be mutated in a variety of cancers [79]. As a result of loss of function of various tumor suppressors, the levels of HIF1A increase, indicating that higher HIF1 activity is a common pathway in the pathogenesis of various human cancers [80]. Mutations in regulators of AKT1 signalling pathway have been known to induce oncogenic transformation in human cell. These have been observed mainly in glioma and endometrial cancer but infrequently in cancers like prostate cancer, melanoma, non-small cell lung cancer, breast cancer and hepatocellular carcinoma [81].

Finally, pathway analysis was performed not taking linked genes into account this time. Pathway Enrichment in Analyze Network Functions was performed in Reactome FI application of Cytoscape to find which cellular pathway is enriched by our query genes and the analysis narrowed to 7 genes: HDAC3, NCOA1, NLRC4, COL1A1, RARA, WWTR1, and BRCA1 which were identified to be involved in RNA polymerase II transcription pathway. It was revealed that the genes were significantly enriched in RNA Polymerase II transcription pathway $(\mathrm{p}=0.002$, FDR $=0.01$ ). RNA Pol II is involved in gene transcription by playing significant role in recruitment, initiation, elongation and dissociation [82, 83]. The role of RNA polymerase II transcription in tumorigenesis has been elucidated in previous studies [84]. It was observed in mouse lymphoma models that tumor cells develop more 
sensitivity to apoptosis when compared to wild-type cells after treatment with RNA polymerase II transcription inhibitors [85-87]. Enhanced transcription of oncogenes and various transcription factors is associated with transformation in cancer cells [88]. Components of transcriptional apparatus, various oncogenes and ribosomal genes get over expressed in tumor cells in order to maintain proliferation [89-91]. RNPII transcription additionally is required to meet the high need of transcripts like oncogenes and anti-apoptotic factors, which is required to support fast growth and resistance to apoptosis [92].

The role of the genes identified in the current analysis, HDAC3, NCOA1, NLRC4, COL1A1, RARA, WWTR1, and $B R C A 1$, has already been documented in carcinogenesis. $H D A C 3$ represses CREB3 mediated transcription and migration of breast cancer cells that are metastatic [93]. NCOA1 promotes angiogenesis in breast tumors by enhancing the transcription of VEGFa via HIF $\alpha$ and AP-1 [94]. Previous studies from our lab on breast cancer patients from same region have reported association of VEGF polymorphisms $+405 \mathrm{C}>\mathrm{G},+936 \mathrm{C}>\mathrm{T},-2549$ Insertion/Deletion, $-152 \mathrm{G} / \mathrm{A},-116 \mathrm{G} / \mathrm{A},-165 \mathrm{C} / \mathrm{T}$ and $-141 \mathrm{~A} / \mathrm{C}$ with breast cancer risk but no association of VEGF $-417 \mathrm{C} / \mathrm{T},-172 \mathrm{C} / \mathrm{A}$ and $-160 \mathrm{C} / \mathrm{T}$ and $\mathrm{HIF} 1 \alpha$ polymorphisms (g.C111A, g.C1772T and g.G1790A) with breast cancer risk [95-98].

Majority of the subjects, patients $(67.3 \%)$ and controls $(84 \%)$, in the present study were obese with increased central obesity. In the context of obesity, the tumor microenvironment induces an enhanced level of tumorinfiltrating myeloid cells with an activated NLRC4 inflammasome which further activates IL-1b, thus driving progression of disease through adipocyte-mediated VEGFA expression and angiogenesis [99]. Obesity might aid the progression of cancer through the pathways linked with NLRC4 and VEGFA. Thus, prevalence of obesity can have implications for breast cancer risk in the present study sample also.

Cellular expression of COL1A1 has been reported to possibly promote breast cancer metastasis. This became evident from a study which reported that high levels of COL1A1 were associated with poor survival and a better response to cisplatin-based chemotherapy was observed in ER+breast cancer patients who had increased COL1A1 levels [100]. Breast cancers displaying RARA amplifications show sensitivity to retinoic acid [101] and thus these subtypes of breast cancers can be treated with targeted therapies [102]. WWTR1 also plays a significant role in migration, invasion and carcinogenesis of breast cancer cells [103]. BRCA1 interacts with a variety of other proteins to carry out multiple functions at cellular level like controlling cell cycle, DNA damage repair, regulation of transcription, replication, recombination and chromatin hierarchical control [104]. In breast cancer patients from same geographical region of north India no association of breast cancer risk with $B R C A 1$ variants c.190 T > C, 1307delT, g.5331G > A and c.2612C > T was observed [105].

Previous reports have also highlighted the significance of integrative analysis of copy number variations and gene expression profiles in breast cancer [106, 107]. The current study employs the information inferred from chromosomal instability for determining the genes and the pathways associated with breast cancer. The genes/ pathways deduced can be further extrapolated by looking for potential mutations that act as key players in breast carcinogenesis. Following up on a lead from the present study, gene expression of the same individuals can be performed. This expression profiling can pinpoint the relevant functional impact of chromosomal instability.

\section{Conclusion}

Breast cancer is a heterogenous disease where mutations in various genes can lead to disease progression. Therefore it becomes important to mark out the cellular pathways involving multiple genes for getting a deeper insight of cancer causation. The present study is a first of its kind where the results of conventional cytogenetics have been exploited to perform gene enrichment analysis. The in silico pathway analysis based on chromosomal instability in PBLs of breast cancer patients hinted towards the RNA polymerase II transcription pathway. Association with breast cancer risk of variants in some of the genes (p53, HIF, BRCA1 and VEGF) involved in this cellular pathway has been reported from the same population of North India. Further experimental work can help in identifying mutated genes in the pathway and sub-networks to find their relation with breast cancer progression and metastasis.

\section{Supplementary information}

Supplementary information accompanies this paper at https://doi. org/10.1186/s12920-020-00811-z.

Additional file 1. Karyotypes of breast cancer patients.

\section{Abbreviations}

CIN: Chromosomal Instability; (N)-CIN: Numerical Chromosomal Instability; (S)-CIN: Structural Chromosomal Instability; NCl: National Cancer Institute; PBLs: Peripheral Blood Lymphocytes; IDC: Infiltrating Ductal Carcinoma; TAM: Total Aberrant Metaphases; MSA: Metaphases with Structural Aberrations; MNA: Metaphases with Numerical Aberrations; M(SA + NA): Metaphases with Structural and Numerical Aberrations; MAA: Metaphases with Acrocentric Associations.

\section{Acknowledgements}

We are thankful to all the subjects who participated in the present study. We would also like to thank Dr. Geeta Sharma, former Principal and Dr. Manjit Singh Uppal, Principal, Sri Guru Ram Das Institute of Medical Sciences and 
Research, Vallah, Amritsar, Punjab for allowing access to patients and other facilities helpful in carrying out the present study.

\section{Authors' contributions}

VS and KG conceptualized and designed the experiment. AK performed the experiments. AK and VS analyzed the results and prepared the manuscript. All the clinicians NRS, MSU, MM, and MS were involved in the acquisition, analysis, correlation and interpretation of the clinical data of patients. NRS and MSU diagnosed the cancer patients and carried out the relevant clinical testing and surgery. The tumor sample excised surgically was used to classify the patients into different stages by MM who carried out the histopathology and hormone receptor related tests. MS correlated the clinical data, the epidemiological data and coordinated the therapy regime of patients. All authors read and approved the final manuscript.

\section{Funding}

Financial assistance from UGC vide project grant F.No. 41-824/2012/(SR) to Dr. Vasudha Sambyal, UGC-UPE and UGC-CPEPA to Dr. Vasudha Sambyal and Dr. Kamlesh Guleria and fellowship from UGC-UPE and CSIR vide F.No. 09/254(0258)/2016-EMR-I to Akeen Kour is highly acknowledged. The grant from UGC included funds for chemicals and contingencies. The grant from CSIR included monthly fellowship and contingency amount.

\section{Availability of data and materials}

The raw datasets generated and/or analyzed during current study are not publicly available in order to protect participant confidentiality. The genes present on the chromosomes involved in anomalies can be accessed from Atlas of Genetics and Cytogenetics in Oncology and Hematology [49] https://atlas geneticsoncology.org/ and Genatlas Database [50] https://genatlas.medec ine.univ-paris5.fr/: On the homepage of Atlas of Genetics and Cytogenetics in Oncology and Hematology, the chromosome number was selected from 'ENTITIES: by chromosomal band' and then the genes present on the particular location/band were identified. These genes have the following atlas ID(s) on the Atlas of Genetics and Cytogenetics in Oncology and Hematology- 1 p32: RNF11 (44,143); 1q21: ARNT (223), SHC1 (42,287), PIP5K1A (47,397), S100A10 (44,145), BCL9 (466), MAD1L1 (41,226), PDE4DIP (180); 2p21: EML4 (44,353); 2p22: NLRC4 (43,189), MSN (363), BIRC6 (798), STRN $(44,243), \operatorname{EIF2AK2~}(41,866)$; 2p23: NCOA1 (44,097), ALK (16); 3p21: LIMD1 (41,158), MAP4 (44,410), RHOA (42,107), PFKFB4 (46,519), MST1 (44,411), SEMA3F (42,254), SETD2 (51,302), PBRM1 (43,697), BAP1 (755), PBRM1 (43,697), PRKCD (42,901); 3q25: WWTR1 (44,545), SIAH2 (46,199), MLF1 (18), RARRES1 (42,050), 4q12: FIP1L1 (40,577); 4q31: INPP4B (43,320), NR3C2 (44,262); 5q31: AFF4 (230), SLIT3 (50,515), VDAC1 (50,902), ANKHD1 (46,476), HDAC3 (40,804), ARHGAP26 (291); 6q13: SMAP1 (42,974); 6q25: RGS17 (47,522), AKAP12 (607), LATS1 (41,127); 6q27: FGFR10P (113), THBS2 (42,549); 7q22: CUX1 (403); 10q21: CCDC6 (280), RHOBTB1 (42,981), ARID5B (51,529); 11 q23: SDHD (390), ARHGEF12 (243); 15q22: PCLAF $(41,058)$, DAPK2 (40,263); 17q21: GSDMB (43,972), RARA (46), CDC6 $(40,014)$, STAT3 (444), GAST (44,214), ACLY (50,486), BRCA1 (163), ETV4 (133), NMT1 (43,604), KPNB1 (41,101), IGF2BP1 (40,969), NGFR $(41,535)$, XYLT2 $(42,852)$, PPP1R9B $(51,558)$, COL1A1 (186). On the homepage of Genatlas Database, the list of genes present on a particular chromosomal location/band was retrieved by entering the chromosome number and band in "SEARCH in GENATLAS GENES" search field.

\section{Ethics approval and consent to participate}

This study was conducted after approval by the institutional ethical committee of Guru Nanak Dev University, Amritsar, Punjab, India. All the subjects gave their written consent to participate in the study and volunteered to provide $5 \mathrm{ml}$ of their blood sample and their personal information. All the study subjects were more than 20 years of age; no children were included in the study. Therefore, parental consent was not obtained.

\section{Consent for publication}

Not applicable.

\section{Competing interests}

Corresponding author, Vasudha Sambyal and co-author Kamlesh Guleria are Associate Editors of the journal BMC Medical Genetics. Rest of the authors declare that they have no competing interests.

\begin{abstract}
Author details
${ }^{1}$ Human Cytogenetics Laboratory, Department of Human Genetics, Guru Nanak Dev University, Amritsar, Punjab, India. ${ }^{2}$ Department of Surgery, Sri Guru Ram Das Institute of Medical Sciences and Research, Vallah, Amritsar, Punjab, India. ${ }^{3}$ Department of Pathology, Sri Guru Ram Das Institute of Medical Sciences and Research, Vallah, Amritsar, Punjab, India. ${ }^{4}$ Department of Radiotherapy, Sri Guru Ram Das Institute of Medical Sciences and Research, Vallah, Amritsar, Punjab, India.
\end{abstract}

Received: 27 January 2020 Accepted: 11 June 2020

Published online: 09 November 2020

\section{References}

1. Bayani J, Paderova J, Murphy J, Rosen B, Zielenska M, Squire JA. Distinct patterns of structural and numerical chromosomal instability characterize sporadic ovarian cancer. Neoplasia (New York, NY). 2008;10(10):1057-65.

2. Cahill DP, Lengauer C, Yu J, Riggins GJ, Willson JK, Markowitz SD, Kinzler KW, Vogelstein B. Mutations of mitotic checkpoint genes in human cancers. Nature. 1998;392(6673):300-3.

3. Kops GJ, Weaver BA, Cleveland DW. On the road to cancer: aneuploidy and the mitotic checkpoint. Nat Rev Cancer. 2005;5(10):773-85.

4. Hoeijmakers JH. Genome maintenance mechanisms for preventing cancer. Nature. 2001:411(6835):366-74.

5. Bayani J, Selvarajah S, Maire G, Vukovic B, Al-Romaih K, Zielenska M, Squire JA (2007) Genomic mechanisms and measurement of structural and numerical instability in cancer cells. Sem Cancer Biol 17(1): 5-18.

6. Stewart SA, Weinberg RA. Telomerase and human tumorigenesis. In Seminars in cancer biology 2000 (Vol. 10, No. 6, pp. 399-406). Academic Press.

7. Nigg EA. Centrosome aberrations: cause or consequence of cancer progression? Nat Rev Cancer. 2002;2(11):815.

8. Choi CM, Seo KW, Jang SJ, Oh YM, Shim TS, Kim WS, Lee DS, Lee SD. Chromosomal instability is a risk factor for poor prognosis of adenocarcinoma of the lung: Fluorescence in situ hybridization analysis of paraffin-embedded tissue from Korean patients. Lung Cancer. 2009;64(1):66-70.

9. Carter SL, Eklund AC, Kohane IS, Harris LN, Szallasi Z. A signature of chromosomal instability inferred from gene expression profiles predicts clinical outcome in multiple human cancers. Nat Genet. 2006:38(9):1043-8.

10. Walther A, Houlston R, Tomlinson I. Association between chromosomal instability and prognosis in colorectal cancer: a meta-analysis. Gut. 2008;57(7):941-50.

11. Gollin SM (2005) Mechanisms leading to chromosomal instability. Semin Cancer Biol 15(1): 33-42

12. Brendle A, Brandt A, Johansson R, Enquist $K$, Hallmans $G$, Hemminki $K$, Lenner P, Försti A. Single nucleotide polymorphisms in chromosomal instability genes and risk and clinical outcome of breast cancer: a Swedish prospective case-control study. Eur J Cancer. 2009:45(3):435-42.

13. Mertens F, Johansson B, Höglund M, Mitelman F. Chromosomal imbalance maps of malignant solid tumors: a cytogenetic survey of 3185 neoplasms. Can Res. 1997;57(13):2765-80.

14. Weaver BA, Cleveland DW. Does aneuploidy cause cancer? Curr Opin Cell Biol. 2006;18(6):658-67.

15. Nowell PC. The clonal evolution of tumor cell populations. Science. 1976;194(4260):23-8

16. McGranahan N, Burrell RA, Endesfelder D, Novelli MR, Swanton C. Cancer chromosomal instability: therapeutic and diagnostic challenges. EMBO Rep. 2012;13(6):528-38.

17. Roschke AV, Lababidi S, Tonon G, Gehlhaus KS, Bussey K, Weinstein JN, Kirsch IR. Karyotypic "state" as a potential determinant for anticancer drug discovery. Proc Natl Acad Sci. 2005;102(8):2964-9.

18. Roschke AV, Kirsch IR. Targeting cancer cells by exploiting karyotypic complexity and chromosomal instability. Cell Cycle. 2005;4(5):679-82.

19. Wallqvist A, Huang R, Covell DG, Roschke AV, Gelhaus KS, Kirsch IR. Drugs aimed at targeting characteristic karyotypic phenotypes of cancer cells. Mol Cancer Ther. 2005;4(10):1559-68. 
20. Habermann JK, Paulsen U, Roblick UJ, Upender MB, McShane LM, Korn EL, Wangsa D, Krüger S, Duchrow M, Bruch HP, Auer G. Stage-specific alterations of the genome, transcriptome, and proteome during colorectal carcinogenesis. Genes Chromosom Cancer. 2007;46(1):10-26.

21. Selvarajah S, Yoshimoto M, Ludkovski O, Park PC, Bayani J, Thorner P, Maire G, Squire JA, Zielenska M. Genomic signatures of chromosomal instability and osteosarcoma progression detected by high resolution array CGH and interphase FISH. Cytogenet Genome Res. 2008;122(1):5-15.

22. Heilig CE, Löffler H, Mahlknecht U, Janssen JW, Ho AD, Jauch A, Krämer A. Chromosomal instability correlates with poor outcome in patients with myelodysplastic syndromes irrespectively of the cytogenetic risk group. J Cell Mol Med. 2010;14(4):895-902.

23. Burrell RA, Juul N, Johnston SR, Reis-Filho JS, Szallasi Z, Swanton C. Targeting chromosomal instability and tumour heterogeneity in HER2positive breast cancer. J Cell Biochem. 2010;111(4):782-90.

24. Wood LD, Parsons DW, Jones S, Lin J, Sjöblom T, Leary RJ, Shen D, Boca SM, Barber T, Ptak J, Silliman N. The genomic landscapes of human breast and colorectal cancers. Science. 2007;318(5853):1 108-13.

25. Jones S, Zhang X, Parsons DW, Lin JC, Leary RJ, Angenendt P, Mankoo P, Carter H, Kamiyama H, Jimeno A, Hong SM. Core signaling pathways in human pancreatic cancers revealed by global genomic analyses. Science. 2008;321(5897):1801-6.

26. Parsons DW, Jones S, Zhang X, Lin JC, Leary RJ, Angenendt P, Mankoo P, Carter H, Siu IM, Gallia GL, Olivi A. An integrated genomic analysis of human glioblastoma multiforme. Science. 2008;321(5897):1807-12.

27. Ding L, Getz G, Wheeler DA, Mardis ER, McLellan MD, Cibulskis K, Sougnez C, Greulich H, Muzny DM, Morgan MB, Fulton L. Somatic mutations affect key pathways in lung adenocarcinoma. Nature. 2008:455(7216):1069.

28. Cancer Genome Atlas Research Network. Comprehensive genomic characterization defines human glioblastoma genes and core pathways. Nature. 2008;455(7216):1061.

29. Pino MS, Chung DC. The chromosomal instability pathway in colon cancer. Gastroenterology. 2010;138(6):2059-72.

30. Vogelstein B, Kinzler KW. Cancer genes and the pathways they control. Nat Med. 2004;10(8):789-99.

31. Vogelstein B, Papadopoulos N, Velculescu VE, Zhou S, Diaz LA, Kinzler KW. Cancer genome landscapes. Science. 2013;339(6127):1546-58.

32. Hanahan D, Weinberg RA. Hallmarks of cancer: the next generation. Cell. 2011;144(5):646-74.

33. Dumont N, Arteaga CL. Transforming growth factor-beta and breast cancer: tumor promoting effects of transforming growth factor- $\beta$. Breast Cancer Res. 2000;2(2):125-32.

34. Donovan J, Slingerland J. Transforming growth factor- $\beta$ and breast cancer: cell cycle arrest by transforming growth factor- $\beta$ and its disruption in cancer. Breast Cancer Res. 2000;2(2):116-24.

35. Kretzschmar M. Transforming growth factor- $\beta$ and breast cancer: transforming growth factor- $\beta / S M A D$ signaling defects and cancer. Breast Cancer Res. 2000;2(2):107-15.

36. Wakefield LM, Yang YA, Dukhanina O. Transforming growth factor- $\beta$ and breast cancer: lessons learned from genetically altered mouse models. Breast Cancer Res. 2000;2(2):100-6.

37. Barcellos-Hoff MH, Ewan KB. Transforming growth factor- $\beta$ and breast cancer: mammary gland development. Breast Cancer Res. 2000;2(2):92-9.

38. Swanton C, Marani M, Pardo O, Warne PH, Kelly G, Sahai E, Elustondo F, Chang J, Temple J, Ahmed AA, Brenton JD. Regulators of mitotic arrest and ceramide metabolism are determinants of sensitivity to paclitaxel and other chemotherapeutic drugs. Cancer Cell. 2007;1 1(6):498-512.

39. Gortzak-Uzan L, Ignatchenko A, Evangelou Al, Agochiya M, Brown KA, St. Onge P, Kireeva I, Schmitt-Ulms G, Brown TJ, Murphy J, Rosen B, . A proteome resource of ovarian cancer ascites: integrated proteomic and bioinformatic analyses to identify putative biomarkers. J Prot Res. 2007;7(1):339-51.

40. Sodek KL, Evangelou Al, lgnatchenko A, Agochiya M, Brown TJ, Ringuette MJ, Jurisica I, Kislinger T. Identification of pathways associated with invasive behavior by ovarian cancer cells using multidimensional protein identification technology (MudPIT). Mol BioSyst. 2008;4(7):762-73.
41. Cava C, Bertoli G, Castiglioni I. Integrating genetics and epigenetics in breast cancer: Biological insights, experimental, computational methods and therapeutic potential. BMC Syst Biol. 2015;9(1):62.

42. Imataka G, Arisaka O. Chromosome analysis using spectral karyotyping (SKY). Cell Biochem Biophys. 2012;62(1):13-7.

43. Hagmar L, Bonassi S, Strömberg U, Brøgger A, Knudsen LE, Norppa H, Reuterwall C. Chromosomal aberrations in lymphocytes predict human cancer: a report from the European Study Group on Cytogenetic Biomarkers and Health (ESCH). Can Res. 1998:58(18):4117-21.

44. Bonassi S, Abbondandolo A, Camurri L, Dal Prá L, De Ferrari M, Degrassi F, Forni A, Lamberti L, Lando C, Padovani P, Sbrana I. Are chromosome aberrations in circulating lymphocytes predictive of future cancer onset in humans? Preliminary results of an Italian cohort study. Cancer Genet Cytogenet. 1995;79(2):133-5.

45. Liou SH, Lung JC, Chen YH, Yang T, Hsieh LL, Chen CJ, Wu TN. Increased chromosome-type chromosome aberration frequencies as biomarkers of cancer risk in a blackfoot endemic area. Can Res. 1999;59(7):1481-4.

46. Bonassi S, Hagmar L, Strömberg U, Montagud AH, Tinnerberg H, Forni A, Heikkilä P, Wanders S, Wilhardt P, Hansteen IL, Knudsen LE. Chromosomal aberrations in lymphocytes predict human cancer independently of exposure to carcinogens. Can Res. 2000;60(6):1619-25.

47. Wang SS, Davis S, Hartge P, Cozen W, Severson RK, Cerhan JR, Rothman N. Chromosomal aberrations in peripheral blood lymphocytes and risk for non-Hodgkin lymphoma. J Natl Cancer InstMonogr. 2008;2008(39):78-82.

48. Schmid M, McGowan-Jordan J, Simons A. An International system for human cytogenomic nomenclature (ISCN 2016). Cytogenet Genome Res. 2016;149:1-2.

49. Atlas of Genetics and Cytogenetics in Oncology and Haematology. https://atlasgeneticsoncology.org/ Accessed 16 September 2019.

50. Winter RM. GENATLAS: Jean Frezal INSERM, Paris. https://genatlas. medecine.univ-paris5.fr/ Accessed 2 October 2019.

51. Weaver BA, Silk AD, Montagna C, Verdier-Pinard P, Cleveland DW. Aneuploidy acts both oncogenically and as a tumor suppressor. Cancer Cell. 2007:11(1):25-36.

52. Thompson SL, Compton DA. Examining the link between chromosomal instability and aneuploidy in human cells. J Cell Biol. 2008;180(4):665-72.

53. Lengauer C, Kinzler KW, Vogelstein B. Genetic instability in colorectal cancers. Nature. 1997;386(6625):623-7.

54. Barber TD, McManus K, Yuen KW, Reis M, Parmigiani G, Shen D, Barrett I, Nouhi Y, Spencer F, Markowitz S, Velculescu VE. Chromatid cohesion defects may underlie chromosome instability in human colorectal cancers. Proc Natl Acad Sci. 2008;105(9):3443-8.

55. Zhang N, Ge G, Meyer R, Sethi S, Basu D, Pradhan S, Zhao YJ, Li XN, Cai WW, El-Naggar AK, Baladandayuthapani V. Overexpression of Separase induces aneuploidy and mammary tumorigenesis. Proc Natl Acad Sci. 2008;105(35):13033-8.

56. Meyer R, Fofanov V, Panigrahi A, Merchant F, Zhang N, Pati D. Overexpression and mislocalization of the chromosomal segregation protein separase in multiple human cancers. Clin Cancer Res. 2009;15(8):2703-10.

57. Iwaizumi M, Shinmura K, Mori H, Yamada H, Suzuki M, Kitayama Y, Igarashi H, Nakamura T, Suzuki H, Watanabe Y, Hishida A. Human Sgol downregulation leads to chromosomal instability in colorectal cancer. Gut. 2009;58(2):249-60.

58. Holland AJ, Cleveland DW. Boveri revisited: chromosomal instability, aneuploidy and tumorigenesis. Nat Rev Mol Cell Biol. 2009;10(7):478-87.

59. Hanks S, Coleman K, Reid S, Plaja A, Firth H, FitzPatrick D, Kidd A, Méhes K, Nash R, Robin N, Shannon N. Constitutional aneuploidy and cancer predisposition caused by biallelic mutations in BUB1B. Nat Genet. 2004;36(11):1159-61.

60. Grabsch H, Takeno S, Parsons WJ, Pomjanski N, Boecking A, Gabbert $\mathrm{HE}$, Mueller W. Overexpression of the mitotic checkpoint genes BUB1, BUBR1, and BUB3 in gastric cancer-association with tumour cell proliferation. J Pathol J PatholSoc Great Br Ireland. 2003;200(1):16-22.

61. Wang $X$, Jin DY, Ng RW, Feng H, Wong YC, Cheung AL, Tsao SW. Significance of MAD2 expression to mitotic checkpoint control in ovarian cancer cells. Can Res. 2002;62(6):1662-8. 
62. Ganem NJ, Godinho SA, Pellman D. A mechanism linking extra centrosomes to chromosomal instability. Nature. 2009;460(7252):278-82.

63. Gregan J, Polakova S, Zhang L, Tolić-Nørrelykke IM, Cimini D. Merotelic kinetochore attachment: causes and effects. Trends Cell Biol. 2011;21(6):374-81.

64. Carmena M, Ruchaud S, Earnshaw WC. Making the Auroras glow: regulation of Aurora $A$ and $B$ kinase function by interacting proteins. Curr Opin Cell Biol. 2009;21(6):796-805.

65. Janssen A, van der Burg M, Szuhai K, Kops GJ, Medema RH. Chromosome segregation errors as a cause of DNA damage and structural chromosome aberrations. Science. 2011;333(6051):1895-8.

66. Crasta K, Ganem NJ, Dagher R, Lantermann AB, Ivanova EV, Pan Y, Nezi L, Protopopov A, Chowdhury D, Pellman D. DNA breaks and chromosome pulverization from errors in mitosis. Nature. 2012;482(7383):53-8.

67. Silva GO, He X, Parker JS, Gatza ML, Carey LA, Hou JP, Moulder SL, Marcom PK, Ma J, Rosen JM, Perou CM. Cross-species DNA copy number analyses identifies multiple 1q21-q23 subtype-specific driver genes for breast cancer. Breast Cancer Res Treat. 2015;152(2):347-56.

68. Wang C, lakovlev VV, Wong V, Leung S, Warren K, lakovleva G, Arneson NC, Pintilie M, Miller N, Youngson B, McCready DR. Genomic alterations in primary breast cancers compared with their sentinel and more distal lymph node metastases: an aCGH study. Genes Chromosom Cancer. 2009;48(12):1091-101.

69. Trapé AP, Gonzalez-Angulo AM. Breast cancer and metastasis: on the way toward individualized therapy. Cancer GenomProteom. 2012;9(5):297-310.

70. Wang HJ, Zhou M, Jia L, Sun J, Shi HB, Liu SL, Wang ZZ. Identification of aberrant chromosomal regions in human breast cancer using gene expression data and related gene information. Med SciMonitlnt Med J ExpClin Res. 2015;21:2557-66.

71. Auer GU, Caspersson TO, Wallgren AS. DNA content and survival in mammary carcinoma. Anal Quant Cytol. 1980;2(3):161-5.

72. Auer G, Eriksson E, Azavedo E, Caspersson T, Wallgren A. Prognostic significance of nuclear DNA content in mammary adenocarcinomas in humans. Can Res. 1984:44(1):394-6.

73. Kronenwett U, Huwendiek S, Östring C, Portwood N, Roblick UJ, Pawitan Y, Alaiya A, Sennerstam R, Zetterberg A, Auer G. Improved grading of breast adenocarcinomas based on genomic instability. Can Res. 2004;64(3):904-9.

74. Kronenwett U, Ploner A, Zetterberg A, Bergh J, Hall P, Auer G, Pawitan Y. Genomic instability and prognosis in breast carcinomas. Cancer Epidemiol Prevent Biomark. 2006;15(9):1630-5.

75. Matsuura S, Matsumoto Y, Morishima KI, Izumi H, Matsumoto H, Ito E, Tsutsui K, Kobayashi J, Tauchi H, Kajiwara Y, Hama S. Monoallelic BUB1B mutations and defective mitotic-spindle checkpoint in seven families with premature chromatid separation (PCS) syndrome. Am J Med Genet Part A. 2006;140(4):358-67.

76. Zhao M, Mishra L, Deng CX. The role of TGF- $\beta / S M A D 4$ signaling in cancer. Int J BiolSci. 2018;14(2):111-23.

77. Attar N, Kurdistani SK. Exploitation of EP300 and CREBBP lysine acetyltransferases by cancer. Cold Spring HarborPerspect Med. 2017:7(3):a026534.

78. Arafeh R, Samuels Y. PIK3CA in cancer: the past 30 years. In Seminars in cancer biology 2019 Feb 10. Academic Press.

79. Aubrey BJ, Strasser A, Kelly GL. Tumor-suppressor functions of the TP53 pathway. Cold Spring HarborPerspect Med. 2016;6(5):a026062.

80. Semenza GL. Defining the role of hypoxia-inducible factor 1 in cancer biology and therapeutics. Oncogene. 2010;29(5):625-34.

81. Kumar A, Purohit R. Cancer associated E17K mutation causes rapid conformational drift in AKT1 pleckstrin homology $(\mathrm{PH})$ domain. PLoS ONE. 2013;8(5):e64364.

82. Fuda NJ, Ardehali MB, Lis JT. Defining mechanisms that regulate RNA polymerase II transcription in vivo. Nature. 2009;461(7261):186-92.

83. Zeitlinger J, Stark A, Kellis M, Hong JW, Nechaev S, Adelman K, Levine M, Young RA. RNA polymerase stalling at developmental control genes in the Drosophila melanogaster embryo. Nat Genet. 2007;39(12):1512-6.

84. Chaudhary K, Deb S, Moniaux N, Ponnusamy MP, Batra SK. Human RNA polymerase II-associated factor complex: dysregulation in cancer. Oncogene. 2007;26(54):7499-507.
85. Koumenis C, Giaccia AM. Transformed cells require continuous activity of RNA polymerase II to resist oncogene-induced apoptosis. Mol Cell Biol. 1997;17(12):7306-16.

86. Radhakrishnan SK, Gartel AL. A novel transcriptional inhibitor induces apoptosis in tumor cells and exhibits antiangiogenic activity. Can Res. 2006;66(6):3264-70.

87. Cho EC, Mitton B, Sakamoto K CREB and leukemogenesis. Crit Rev Oncogenesis. 2011;16(1):37-46

88. Bywater MJ, Pearson RB, McArthur GA, Hannan RD. Dysregulation of the basal RNA polymerase transcription apparatus in cancer. Nat Rev Cancer. 2013;13(5):299-314.

89. Drygin D, Rice WG, Grummt I. The RNA polymerase I transcription machinery: an emerging target for the treatment of cancer. Annu Rev Pharmacol Toxicol. 2010;50:131-56.

90. Adhikary S, Eilers M. Transcriptional regulation and transformation by Myc proteins. Nat Rev Mol Cell Biol. 2005;6(8):635-45.

91. Cabarcas S, Schramm L. RNA polymerase III transcription in cancer: the BRF2 connection. Mol Cancer. 2011;10(1):47-57.

92. Villicaña C, Cruz G, Zurita M. The basal transcription machinery as a target for cancer therapy. Cancer Cell Int. 2014;14(1):18.

93. Kim HC, Choi KC, Choi HK, Kang HB, Kim MJ, Lee YH, Lee OH, Lee J, Kim YJ, Jun W, Jeong JW. HDAC3 selectively represses CREB3-mediated transcription and migration of metastatic breast cancer cells. Cell Mol Life Sci. 2010;67(20):3499-510.

94. Qin L, Xu Y, Xu Y, Ma G, Liao L, Wu Y, Li Y, Wang X, Wang X, Jiang J, Wang J. NCOA1 promotes angiogenesis in breast tumors by simultaneously enhancing both HIF1a-and AP-1-mediated VEGFa transcription. Oncotarget. 2015;6(27):23890-904.

95. Kapahi R, Manjari M, Uppal MS, Singh NR, Sambyal V, Guleria K. Association of - 2549 insertion/deletion polymorphism of vascular endothelial growth factor with breast cancer in North Indian patients. Genetic Test MolBiomark. 2013;17(3):242-8.

96. Kapahi R, Guleria K, Sambyal V, Manjari M, Sudan M, Uppal MS, Singh NR. Vascular endothelial growth factor (VEGF) gene polymorphisms and breast cancer risk in Punjabi population from North West India. TumorBiol. 2014;35(11):11171-81.

97. Kapahi R, Manjari M, Sudan M, Uppal MS, Singh NR, Sambyal V, Guleria K. Association of $+405 C>G$ and $+936 C>T$ polymorphisms of the vascular endothelial growth factor gene with sporadic breast cancer in North Indians. Asian Pac J Cancer Prev. 2014:15(1):257-63.

98. Sharma S, Kapahi R, Sambyal V, Guleria K, Manjari M, Sudan M, Uppal MS, Singh NR. No association of hypoxia inducible factor-1 a gene polymorphisms with breast cancer in North-West Indians. Asian Pac J Cancer Prev. 2014;15(22):9973-8.

99. Kolb R, Phan L, Borcherding N, Liu Y, Yuan F, Janowski AM, Xie Q, Markan KR, Li W, Potthoff MJ, Fuentes-Mattei E. Obesity-associated NLRC4 inflammasome activation drives breast cancer progression. Nature communications. 2016;7:13007

100. Liu J, Shen JX, Wu HT, Li XL, Wen XF, Du CW, Zhang GJ. Collagen 1A1 (COL1A1) promotes metastasis of breast cancer and is a potential therapeutic target. Discov Med. 2018;25(139):211-23.

101. Alsafadi S, Even C, Falet C, Goubar A, Commo F, Scott V, Quidville V, Albiges L, Dieci MV, Guegan J, Lazar V. Retinoic acid receptor alpha amplifications and retinoic acid sensitivity in breast cancers. Clin Breast Cancer. 2013;13(5):401-8.

102. Johansson HJ, Sanchez BC, Mundt F, Forshed J, Kovacs A, Panizza E, Hultin-Rosenberg L, Lundgren B, Martens U, Máthé G, Yakhini Z. Retinoic acid receptor alpha is associated with tamoxifen resistance in breast cancer. Nature communications. 2013:4:2175.

103. Chan SW, Lim CJ, Guo K, Ng CP, Lee I, Hunziker W, Zeng Q, Hong W. A role for TAZ in migration, invasion, and tumorigenesis of breast cancer cells. Can Res. 2008;68(8):2592-8.

104. Parvin JD. Overview of history and progress in BRCA1 research: the first BRCA1 decade. Cancer Biol Ther. 2004;3(6):505-8.

105. Kour A, Sambyal V, Guleria V, Singh NR, Uppal MS, Manjari M and Sudan M. Screening of BRCA1 variants C.190T>C, 1307delT, g.5331G $>A$ and c.2612C $>$ T in breast cancer patients from North India. Genetics and molecular biology. 2020;43(2) (In Press).

106. Bergamaschi A, Kim YH, Wang P, Sørlie T, Hernandez-Boussard T, Lonning PE, Tibshirani R, Børresen-Dale AL, Pollack JR. Distinct patterns of DNA copy number alteration are associated with different 
clinicopathological features and gene-expression subtypes of breast cancer. Genes Chromosom Cancer. 2006;45(11):1033-40.

107. Kao J, Salari K, Bocanegra M, Choi YL, Girard L, Gandhi J, Kwei KA, Hernandez-Boussard T, Wang P, Gazdar AF, Minna JD. Molecular profiling of breast cancer cell lines defines relevant tumor models and provides a resource for cancer gene discovery. PLoS ONE. 2009;4(7):e6146.

\section{Publisher's Note}

Springer Nature remains neutral with regard to jurisdictional claims in published maps and institutional affiliations.
Ready to submit your research? Choose BMC and benefit from:

- fast, convenient online submission

- thorough peer review by experienced researchers in your field

- rapid publication on acceptance

- support for research data, including large and complex data types

- gold Open Access which fosters wider collaboration and increased citations

- maximum visibility for your research: over $100 \mathrm{M}$ website views per year

At BMC, research is always in progress.

Learn more biomedcentral.com/submissions 